\title{
Fate of Escherichia coli O157:H7, Salmonella spp., and Listeria monocytogenes During Curing and Drying of Beef Bresaola
}

\author{
Samuel C. Watson ${ }^{1}$, Nelson J. Gaydos ${ }^{2}$, Samantha R. Egolf ${ }^{3}$, and Jonathan A. Campbell ${ }^{1 *}$ \\ ${ }^{1}$ Department of Animal Science, The Pennsylvania State University, University Park, PA 16802, USA \\ ${ }^{2}$ American Association of Meat Processors, Elizabethtown, PA 17022, USA \\ ${ }^{3}$ Department of Animal Science, The South Dakota State University, Brookings, SD 57007, USA \\ *Corresponding author. Email: meatscience@psu.edu (Jonathan A. Campbell)
}

\begin{abstract}
Manufacturing dry-cured meat products without a thermal lethality step is a growing trend for charcuterie companies in the United States. The United States Department of Agriculture Food Safety and Inspection Service requires that hazards for ready-to-eat meat products be addressed with a scientifically valid Hazard Analysis Critical Control Point system. Because little validation literature exists for these products, an experiment was designed to investigate the safety of beef bresaola. The objective of this study was to determine the reduction of Escherichia coli O157:H7, Salmonella spp., and Listeria monocytogenes during curing and drying of bresaola. Prior to curing, whole beef semitendinosus muscle was inoculated with a mixed culture containing 3 strains each of E. coli O157:H7, Salmonella spp., and L. monocytogenes, allowed to air dry $\left(30 \mathrm{~min}\right.$ at $\left.23^{\circ} \mathrm{C}\right)$, sprayed with a $2.5 \%$ Beefxide antimicrobial treatment (Birko Corp., Henderson, CO), and allowed to sit overnight in a walk-in cooler $\left(2^{\circ} \mathrm{C}-4^{\circ} \mathrm{C}\right)$. Cure $\left(\mathrm{NaNO}_{3}\right.$ and $\left.\mathrm{NaNO}_{2}\right)$ and salt were applied to the beef surface $24 \mathrm{~h}$ after the antimicrobial treatment, and the beef was cured for $28 \mathrm{~d}\left(2^{\circ} \mathrm{C}-4^{\circ} \mathrm{C}\right)$. Following curing, a proprietary spice mixture was surface coated, and each piece was stuffed into beef casings $(115-130 \mathrm{~mm})$. The stuffed bresaola pieces were hung and allowed to dry for $35 \mathrm{~d}$ to a target water activity $<0.92\left(13.63^{\circ} \mathrm{C} \pm 2{ }^{\circ} \mathrm{C}\right.$; relative humidity $\left.68 \% \pm 7 \%\right)$. Pathogen populations and water activity were analyzed on days 0,1 , and 2 and then weekly until day 65 of the study. Final reductions of 5.97, 5.98, and $5.44 \log _{10}$ colony-forming units (CFU)/ $\mathrm{cm}^{2}$ were achieved on day 65 for E. coli, Salmonella spp., and L. monocytogenes, respectively. During the entire curing and drying process, populations of each species never increased by more than $0.5 \log _{10} \mathrm{CFU} / \mathrm{cm}^{2}$. The critical parameters used to cure and dry this product are sufficient to achieve the minimum $5 \log _{10} \mathrm{CFU} / \mathrm{cm}^{2}$ reduction of each pathogen as required by the United States Department of Agriculture Food Safety and Inspection Service to validate process safety.
\end{abstract}

Key words: bresaola, dry-cured, Escherichia coli O157:H7, Salmonella, Listeria monocytogenes Meat and Muscle Biology 5(1): 14, 1-8 (2021) doi:10.22175/mmb.11621

Submitted 4 August $2020 \quad$ Accepted 20 January 2021

\section{Introduction}

Salting, curing, and drying have been utilized as meat preservation methods for thousands of years, and whole-muscle meat products like prosciutto and bresaola were among the first products to be developed by ancient societies throughout Europe (Zeuthen, 2007; Zhou et al., 2010; Ruhlman and Polcyn, 2012). As the charcuterie and salumi industry in the United
States has grown and expanded, artisanal and wholesale producers alike are recreating these ancient products using techniques that have been maintained through the centuries. Traditionally, bresaola was produced with whole beef muscles like semitendinosus (eye of round) or semimembranosus (inside round), and products were not cooked prior to consumption. Eye of round or similar beef cuts were coated with salt and spices, stuffed into casings, or wrapped in skin and then were hung to be dried. The finished bresaola was sliced and consumed once 
enough water had been removed from the product (Zeuthen, 2007; Zhou et al., 2010; Ruhlman and Polcyn, 2012).

Bresaola is generally considered safe to consume without thermal treatment and relies heavily upon hurdle technology and the hurdle effect to achieve bacterial safety (Leistner and Gorris, 1995; Leistner, 2000). For example, bresaola and other whole-muscle charcuterie products rely primarily on the collective use of salt and drying in order to reduce water activity $\left(a_{W}\right)$ in the final product, which is detrimental to the survival and growth of any pathogens present (Sperber, 1983; Beales, 2004). These intrinsic and extrinsic stressors for pathogenic cells may be metabolic or structural. Metabolic stress inhibits growth by increasing the osmotic pressure of the meat system, causing bacterial cells to expend a greater amount of energy maintaining internal water and ion homeostasis. Pathogens that are prevented from growing in a low $a_{W}$ environment are hindered because energy is used to maintain homeostasis rather than multiplication, and death of the pathogen occurs when the cell has become metabolically exhausted (Sperber, 1983; Beales, 2004). Structural stress of the pathogenic cell can cause morphology changes in shape or even composition changes of the cell membrane, specifically, fatty acids and lipids that play a role in membrane permeability and structural integrity (Harvey and Leach, 1998; Rowan, 1999; Murga et al., 2000; Guerzoni et al., 2001). Several curing formulations, either directly or indirectly, utilize a nitrate or nitrite source. In addition to preventing the germination of Clostridium botulinum spores, nitrite, and/or nitrate are bactericidal to other microorganisms that may be present in or on meat products (Majou and Christieans, 2018). Although the mechanism by which nitrate and/or nitrite cause death of pathogens is not completely understood, it is known that once sodium nitrite $\left(\mathrm{NaNO}_{2}\right)$ is added to a meat product, some of the $\mathrm{NaNO}_{2}$ is converted to nitrous acid, a chemical that negatively impacts bacterial cellular processes (Hospital et al., 2014; Majou and Christieans, 2018).

Despite the effectiveness of hurdle technology for improving the safety of meat products, the presence of pathogens in a raw, ready-to-eat (RTE) product such as bresaola is still of concern. It is well known that beef cattle are a natural reservoir for pathogenic Escherichia coli, a microorganism that can be present on beef surfaces contaminated during the harvest and fabrication process (Elder et al., 2000; Barkocy-Gallagher et al., 2005; Duffy et al., 2006; Brichta-Harhay et al., 2008; Castro et al., 2017). According to the United States Department of Agriculture Food Safety and
Inspection Service (USDA-FSIS), E. coli O157:H7 $(E c)$ and other Shiga toxin-producing $E$. coli are the pathogens of highest concern in products containing beef. $E c$ may be the most severe among pathogenic cells capable of producing Shiga toxin because of its low infectious dose (10 or fewer viable cells). Infections by this pathogen result in severe disease, especially in immunocompromised individuals (Montville et al., 2012), and the USDA-FSIS considers all Shiga toxin-producing $E$. coli to be an adulterant in beef products (USDA-FSIS, 2014a). Nontyphoidal Salmonella enterica ssp. enterica ( $\mathrm{Sal}$ ) is also a concern in beef products, and although Sal does not produce toxin, the bacterium is able to cause severe enterocolitic disease that can result in death (Montville et al., 2012; Fàbrega and Vila, 2013). Listeria monocytogenes $(\mathrm{Lm})$ is also of great concern for all RTE meat products, especially those that are not subjected to a thermal processing step during production. $\mathrm{Lm}$ can form and persist in biofilms in the food-processing environment and grow under refrigeration, thus creating the potential for contamination of finished product (Hill et al., 2002; Gandhi and Chikindas, 2007; Swaminathan and Gerner-Smidt, 2007; Ferreira et al., 2014). Because of the growth parameters of $\mathrm{Lm}$ and high mortality rate caused by listeriosis, the USDA-FSIS employs a zero-tolerance policy for the presence of $L m$ in RTE meat products (USDAFSIS, 2014b).

The US Code of Federal Regulations states that meat-processing establishments should conduct a hazard analysis of "food safety hazards reasonably likely to occur" and that preventative measures, backed by scientific evidence, be established to control the identified hazards for all products produced (Federal Register, 1996). Additionally, the USDA-FSIS requires that $E c, L m$, and $S a l$ be controlled during the production of beef bresaola $\left(\geq 5 \log _{10}\right.$ reduction of pathogens) to ensure product safety (USDA-FSIS, 2017). Experimental trials conducted in a laboratory setting that replicate, as best as possible, the conditions in processing environments are commonly accepted by regulators as a method of validating an individual production process for RTE products (Scott, 2005). Therefore, the objectives of this research were to validate a production process of raw, RTE beef bresaola according to USDA-FSIS regulations and to achieve a $5 \log _{10}$ reduction in $E c$, Sal, and $L m$ by the end of processing. The results of this experiment could be used as scientifically valid support for the safe production of raw, RTE bresaola for Hazard Analysis Critical Control Point documentation as well as to fill a 
significant gap in the literature on the safety of wholemuscle charcuterie products.

\section{Materials and Methods}

\section{Preparation of pathogens}

Beef Round, eye of round subprimals (Institutional Meat Purchasing Specifications 171C) were received frozen directly from a meat processor in the northeast. For each of 4 independent replications, beef subprimals $(n=6)$ were thawed $\left(2^{\circ} \mathrm{C}-4^{\circ} \mathrm{C}\right)$ in a walk-in cooler and challenged over the course of curing and drying with a pathogen cocktail of 3 strains each of the following: $E c$, Sal (Typhimurium, Montevideo, and Panama), and $L m$. Pathogenic cultures were obtained from the American Type Culture Collection (Manassas, VA), the Centers for Disease Control and Prevention (Atlanta, GA), and the Pennsylvania State University Department of Food Science (University Park, PA) (Table 1). Frozen stocks were aseptically transferred to sterile tryptic soy broth (TSB; Hardy Diagnostics, Santa Maria, CA) and aerobically incubated at $37^{\circ} \mathrm{C}$ for $24 \mathrm{~h}$. The $24-\mathrm{h}$ cultures were then streaked onto selective media and confirmed for pathogen type using agglutination testing (Microgen Bioproducts, Camberley, UK). Single colonies of each pathogen type were transferred to $10 \mathrm{~mL}$ of TSB and incubated for $24 \mathrm{~h}$, as previously described. The $10 \mathrm{~mL}$ cultures were then transferred to $240 \mathrm{~mL}$ of TSB and grown to a cell concentration of $\sim 8.5$ $\log _{10}$ colony-forming units $(\mathrm{CFU}) / \mathrm{mL}$. Equal volumes $(250 \mathrm{~mL})$ of each strain were mixed in a sterile metal bin under a biological safety cabinet to create a total

Table 1. Type and source of pathogens

\begin{tabular}{ll}
\hline \hline Organism & \multicolumn{1}{c}{ Source } \\
\hline Escherichia coli $\mathrm{O} 157: \mathrm{H} 7$ & ATCC 43865 \\
Escherichia coli $\mathrm{O} 157: \mathrm{H7}$ & ATCC BAA-460 \\
$\begin{array}{l}\text { Escherichia coli O157:H7 strain PA-2 } \\
\text { Salmonella enterica } \text { ssp. enterica }\end{array}$ & Penn State Food Science \\
serovar Typhimurium & ATCC 14028 \\
$\begin{array}{l}\text { Salmonella enterica } \text { ssp. enterica } \\
\text { serovar Panama }\end{array}$ & ATCC 7378 \\
$\begin{array}{l}\text { Salmonella enterica } \text { ssp. enterica } \\
\text { serovar Montevideo }\end{array}$ & CDC 013 \\
$\begin{array}{l}\text { Listeria monocytogenes Scott A } \\
\text { Listeria monocytogenes serotype 4b } \\
\text { isolate H3396 }\end{array}$ & Penn State Food Science \\
Listeria monocytogenes serotype & Penn State Food Science \\
1/2a isolate J1-129 & Penn State Food Science \\
\hline
\end{tabular}

ATCC = American Type Culture Collection; $\mathrm{CDC}=$ Centers for Disease Control and Prevention. volume of $2.25 \mathrm{~L}$ for the homogenized inoculation immersion bath.

\section{Inoculation and processing procedures}

The experiment was conducted in 4 independent replications in the Penn State Food Safety Pilot Plant, a Centers for Disease Control and Prevention Biosafety Level 2 facility. For each replication, 6 eye of round subprimals $(n=6)$ were submerged in the prepared inoculum $\left(\sim 8.5 \log _{10} \mathrm{CFU} / \mathrm{mL}\right)$ immersion bath for approximately $30 \mathrm{~min}$ under a biological safety cabinet $\left(\sim 23^{\circ} \mathrm{C}\right)$ to a target level of $6-7 \log _{10} \mathrm{CFU} /$ $\mathrm{cm}^{2}$. The subprimals were transferred to a sterile plastic bin (uncovered) and allowed to dry for approximately $30 \mathrm{~min}$ at $\sim 4^{\circ} \mathrm{C}$, rotating approximately every $10 \mathrm{~min}$ in the bin. After drying, a 1:40 (2.5\% vol/vol $)$ solution of fresh Beefxide antimicrobial (Birko Corp., Henderson, $\mathrm{CO})$ was sprayed onto the meat surface using a handpump tank sprayer (H.D. Hudson Mfr. Co., Chicago, IL) to evenly cover all surfaces of the product. Briefly, the spray nozzle was kept approximately $10-12 \mathrm{~cm}$ from the product surface. The wand was moved back and forth in a sweeping motion the length of each eye of round from end to end and then repeated in the same pattern backward. Spraying of the product surface was about $15-20 \mathrm{~s}$ on each side before the product was rotated 180 degrees and sprayed again to coat all surfaces. The eye of round subprimals then were transferred to $\sim 4^{\circ} \mathrm{C}$ walk-in cooler. Twenty-four hours following the antimicrobial spray treatment, the eye of round subprimals were cured by applying half of the total curing mixture, a proprietary blend of salt $(3.5 \%$ of meat weight) and cure ingredients $\left(\mathrm{NaNO}_{2}[150\right.$ ppm] and sodium nitrate $\left.\left[\mathrm{NaNO}_{3} ; 100 \mathrm{ppm}\right]\right)$. After being coated with the dry ingredients, the beef was placed in a food-grade, plastic, sterile meat lug at $4^{\circ}$ $\mathrm{C}$, covered, and allowed to cure at $4^{\circ} \mathrm{C}$ for approximately $7 \mathrm{~d}$ before being coated again with the remaining half of the cure mixture. The eye of round subprimals remained in the $4{ }^{\circ} \mathrm{C}$ walk-in cooler for a total of $4 \mathrm{wk}$ before being hand stuffed into 115 - to $130-\mathrm{mm}$ beef bung casings (Globe Casing, Carlstadt, NJ) that had been treated with a $2.5 \%$ Beefxide antimicrobial solution prior to use. The bresaola was tied with butcher twine (24 ply; UltraSource USA, Kansas City, MO) and transferred to an AS50 drying cabinet (Impianti Condizionamento Salumifici; Camposanto, Modena, Italy) at $12^{\circ} \mathrm{C}-14^{\circ} \mathrm{C}$ (average $13.63^{\circ} \mathrm{C} \pm 2{ }^{\circ} \mathrm{C}$ ) and $65 \%-75 \%$ relative humidity (average $68 \% \pm 7 \%$ ). Temperature and humidity were monitored using a HOBO UX100-003 data logger (Onset Computer 
Corp., Bourne, MA). Total curing and drying occurred over a period of $65 \mathrm{~d}$ to a target surface $a_{W}$ of $<0.92$.

\section{Sampling for microbial populations and water activity}

Samples for microbial populations were taken on day 0 (after inoculation but prior to antimicrobial treatment), day 1 (after antimicrobial treatment but prior to addition of salt and cure ingredients), day 2 (approximately $24 \mathrm{~h}$ after addition of salt), and then every $7 \mathrm{~d}$ beginning on day 9 until day 65. At each sampling time, 4 eye of round subprimals were randomly selected to evaluate the microbial populations $(n=3)$ and to measure $a_{W}(n=1)$. Using a $5 \mathrm{~cm} \times 5 \mathrm{~cm}$ stainless steel template, a $25 \mathrm{~cm}^{2}$ piece was cut from the surface of the meat (avoiding previously sampled areas) using a disposable, sterile scalpel (Bard-Parker; Aspen Surgical, Caledonia, MI) and placed into a $400 \mathrm{~mL}$ stomacher bag (BagFilter; Interscience, Woburn, MA). Twenty-five milliliters of $1 \mathrm{X}$ phosphate-buffered saline solution ( $\mathrm{pH}$ 7.2; Hardy Diagnostics, Santa Maria, CA) was added to the sterile stomacher bag, and the sample was homogenized for $3 \mathrm{~min}$ at 260 rpm (Stomacher 400 Circulator; Seward Limited, West Sussex, UK). The stomachate from each sample was serially diluted into $9 \mathrm{~mL}$ of $1 \mathrm{X}$ phosphate-buffered saline, and aliquots of $0.1 \mathrm{~mL}$ were spread plated in duplicate onto selective agar to achieve a detection limit of $0.69 \log _{10} \mathrm{CFU} / \mathrm{cm}^{2}$. The stomachate was plated in $0.5 \mathrm{~mL}$ aliquots in quadruplicate when microbial populations were below the original detection limit. Enumeration of $E c, S a l$, and $L m$ was performed using Cefixime Tellurite Sorbitol MacConkey agar (Remel, Lenexa, KS), Xylose Lysine Deoxycholate agar (Remel), and modified Oxford agar with antibiotic supplement (BD, Sparks, MD), respectively. Cefixime Tellurite Sorbitol MacConkey agar and Xylose Lysine Deoxycholate agar plates were incubated aerobically at $37^{\circ} \mathrm{C}$ for $24 \mathrm{~h}$, and modified Oxford agar with antibiotic supplement plates were incubated aerobically for $48 \mathrm{~h}$ at $37^{\circ} \mathrm{C}$. When no colonies were enumerated, the stomachate sample was enriched (simultaneously during plating) to determine the presence of $E c, S a l$, and $L m$. Enrichments were performed using the USDA Microbiology Laboratory Guidebook methodology. Gram-negative broth (Difco Laboratories, Franklin Lakes, NJ) was used to enrich for $E c$, whereas lactose broth (primary; HiMedia, Mumbai, India) and Rappaport-Vassiliadis (secondary; Remel Products, Lenexa, KS) broth was used for determination of Sal. University of Vermont Medium (Difco Laboratories) and Fraser broth (Difco Laboratories) were used as primary and secondary enrichments to determine the presence of Lm. $a_{w}$ was measured using a calibrated AquaLab 4TE dew point meter (Decagon Devices, Pullman, WA). Briefly, the $25 \mathrm{~cm}^{2}$ surface piece removed from the surface of the eye of round was trimmed to fit in the round sample cup. The cup was inserted into the chamber and the chamber locked to initiate measurement.

\section{Statistical analysis}

Concentrations of $E c, S a l$, and $\mathrm{Lm}$ were analyzed independently using a General Linear Model with unique consecutive comparisons $(\alpha=0.05)$ (SAS version 9.4, SAS Institute, Inc., Cary, NC). To maintain statistical power, comparisons were made between the pathogen concentration average from one sampling time and the concentration of the same pathogen on the following sampling time. No comparisons were made between pathogens. Statistical analysis was not used for $a_{W}$ data.

\section{Results}

Reductions greater than $5 \log _{10} \mathrm{CFU} / \mathrm{cm}^{2}$ were achieved for each pathogen by the end of processing on day 65. Ec, Sal, and $L m$ achieved final reductions 5.97, 5.98, and $5.44 \log _{10} \mathrm{CFU} / \mathrm{cm}^{2}(P<0.00001$ for each), respectively (Table 2). Table 2 shows the mean population of each pathogen for each sampling day and the cumulative $\log _{10}$ reduction during the 65 -d process. Steady reductions of each pathogen occurred over the duration of the curing and drying process. The antimicrobial intervention achieved between 0.50 and 0.90 log reductions, depending on pathogen type $(P<0.05$ for each). $L m$ was the first pathogen to achieve a $5 \log _{10}$ reduction with a reduction of $5.21 \log _{10} \mathrm{CFU} / \mathrm{cm}^{2}$ occurring on day 37. Ec and Sal first achieved $5 \log _{10}$ reductions on day 44 with reductions of 5.52 and 5.74 $\log _{10} \mathrm{CFU} / \mathrm{cm}^{2}$, respectively $(P<0.05)$. It is important to note that the populations of all 3 pathogens never increased greater than $0.5 \log _{10} \mathrm{CFU} / \mathrm{cm}^{2}$ at any time during sampling, indicating that no growth of pathogens occurred during processing. Because the eye of round subprimals were intact whole-muscle roasts and not injected or tenderized, the interior of the bresaola was presumed to be sterile, and only surface measurements of microbial populations are reported. The final surface $a_{W}$ of the bresaola was 0.84 (0.88 internal) and was below the target finished $a_{W}$ of 0.92 . The $a_{W}$ 
Table 2. Mean pathogen levels ( $\log _{10} \mathrm{CFU} / \mathrm{cm}^{2} \pm$ standard error) and cumulative $\log _{10}$ reduction of Escherichia coli O157:H7 (Ec), Salmonella spp. (Sal), and Listeria monocytogenes $(\operatorname{Lm} ; n=24)$, and $a_{W}(n=4)$ of bresaola at sampling days

\begin{tabular}{|c|c|c|c|c|c|c|c|}
\hline Day & $E c$ & $E c$ Reduction & Sal & Sal Reduction & $\mathrm{Lm}$ & $\mathrm{Lm}$ Reduction & $\overline{a W}$ \\
\hline 0 & $6.42 \pm 0.03$ & - & $6.38 \pm 0.05$ & - & $6.35 \pm 0.05$ & - & 0.99 \\
\hline 1 & $5.91 \pm 0.08$ & $\begin{array}{c}0.51 \\
(P=0.0004)\end{array}$ & $5.59 \pm 0.05$ & $\begin{array}{c}0.79 \\
(P<0.0001)\end{array}$ & $5.62 \pm 0.05$ & $\begin{array}{c}0.73 \\
(P<0.0001)\end{array}$ & 0.94 \\
\hline 2 & $4.94 \pm 0.07$ & $\begin{array}{c}1.48 \\
(P<0.0001)\end{array}$ & $4.37 \pm 0.10$ & $\begin{array}{c}2.04 \\
(P<0.0001)\end{array}$ & $4.58 \pm 0.10$ & $\begin{array}{c}1.76 \\
(P<0.0001)\end{array}$ & 0.94 \\
\hline 9 & $4.88 \pm 0.10$ & $\begin{array}{c}1.54 \\
(P=0.6978)\end{array}$ & $4.53 \pm 0.12$ & $\begin{array}{c}1.84 \\
(P=0.1616)\end{array}$ & $4.73 \pm 0.12$ & $\begin{array}{c}1.62 \\
(P=0.2382)\end{array}$ & 0.92 \\
\hline 16 & $3.80 \pm 0.05$ & $\begin{array}{c}2.62 \\
(P<0.0001)\end{array}$ & $3.57 \pm 0.07$ & $\begin{array}{c}2.81 \\
(P<0.0001)\end{array}$ & $3.68 \pm 0.07$ & $\begin{array}{c}2.66 \\
(P<0.0001)\end{array}$ & 0.89 \\
\hline 23 & $3.31 \pm 0.18$ & $\begin{array}{c}3.11 \\
(P=0.0006)\end{array}$ & $2.50 \pm 0.20$ & $\begin{array}{c}3.88 \\
(P<0.0001)\end{array}$ & $3.52 \pm 0.17$ & $\begin{array}{c}2.83 \\
(P=0.1784)\end{array}$ & 0.88 \\
\hline 30 & $3.13 \pm 0.07$ & $\begin{array}{c}3.30 \\
(P=0.1954)\end{array}$ & $2.61 \pm 0.07$ & $\begin{array}{c}3.76 \\
(P=0.4049)\end{array}$ & $3.29 \pm 0.10$ & $\begin{array}{c}3.06 \\
(P=0.0557)\end{array}$ & 0.88 \\
\hline 37 & $1.98 \pm 0.12$ & $\begin{array}{c}4.44 \\
(P<0.0001)\end{array}$ & $1.55 \pm 0.04$ & $\begin{array}{c}4.83 \\
(P<0.0001)\end{array}$ & $1.14 \pm 0.10$ & $\begin{array}{c}5.21 \\
(P<0.0001)\end{array}$ & 0.85 \\
\hline 44 & $0.90 \pm 0.12$ & $\begin{array}{c}5.52 \\
(P<0.0001)\end{array}$ & $0.64 \pm 0.09$ & $\begin{array}{c}5.74 \\
(P<0.0001)\end{array}$ & $1.11 \pm 0.04$ & $\begin{array}{c}5.24 \\
(P=0.8556)\end{array}$ & 0.85 \\
\hline 51 & $0.66 \pm 0.18$ & $\begin{array}{c}5.76 \\
(P=0.0957)\end{array}$ & $0.65 \pm 0.17$ & $\begin{array}{c}5.72 \\
(P=0.9261)\end{array}$ & $0.93 \pm 0.09$ & $\begin{array}{c}5.42 \\
(P=0.1303)\end{array}$ & 0.85 \\
\hline 58 & $0.50 \pm 0.10$ & $\begin{array}{c}5.92 \\
(P=0.242)\end{array}$ & $0.41 \pm 0.08$ & $\begin{array}{c}5.97 \\
(P=0.086)\end{array}$ & $0.70 \pm 0.06$ & $\begin{array}{c}5.65 \\
(P=0.0578)\end{array}$ & 0.83 \\
\hline 65 & $0.45 \pm 0.11$ & $\begin{array}{c}5.97 \\
(P=0.7399)\end{array}$ & $0.40 \pm 0.07$ & $\begin{array}{c}5.98 \\
(P=0.9222)\end{array}$ & $0.91 \pm 0.07$ & $\begin{array}{c}5.44 \\
(P=0.0834)\end{array}$ & 0.84 \\
\hline
\end{tabular}

Statistical comparisons of pathogen concentration were made between each sample day consecutively $(n=24, \alpha=0.05)$ within pathogen type.

$a_{W}=$ water activity; $\mathrm{CFU}=$ colony-forming units.

first dropped below 0.92 during curing on day 16 and remained below 0.92 until the end of processing. During the first week of drying (day 30-37), surface $a_{W}$ dropped from 0.88 to 0.85 .

\section{Discussion}

There has been a recent trend of processing raw, RTE beef products in the US; however, there is little scientific literature supporting their safety. To our knowledge, this bresaola research is the first to demonstrate the viability of a production process for raw, RTE beef challenged with $E c$, Sal, and $\mathrm{Lm}$ to meet FSIS regulatory standards. Burnham et al. (2008) investigated the lethality of pathogens during the processing of biltong and droëwors, dried beef snacks of South African origins. Of the 2 product types examined, biltong is most similar to bresaola because both are whole muscle pieces. Results from the biltong research showed a 3-4 $\log _{10}$ reduction in Ec, Sal, and $L m$ from curing and drying alone. The authors concluded that the parameters used to produce biltong were lethal to pathogens, but raw material testing of each production lot would be needed in combination with the production parameters to validate the process. It is important to note that Burnham et al. (2008) did not incorporate any form of antimicrobial intervention (organic acid spray or dip) that was shown to be effective in the current study; however, the finished $a_{W}(0.85$ and 0.60$)$ was quite lethal to pathogens. $a_{W}$ is perhaps one of the most important intrinsic factors deterring growth and limiting survival of microorganisms. Scott (1957) investigated the minimum $a_{W}$ for growth of many bacteria, indicating that growth below 0.85 for the pathogens investigated in the current study should not occur. It is difficult to compare in-going salt or curing ingredients between the biltong and bresaola processes because the biltong study measured finished percent water-phase salt and not salt on an in-going basis. The reductions of pathogens during the production of bresaola further demonstrate the utility of hurdle technology in meat processing and relevance to product safety. Although the current experiment did not evaluate the efficacy of utilizing various types of organic acid treatments during the production of bresaola, this research provides support for the use of organic acid (acetic. lactic, citric, peracetic acid, etc.) 
treatments of raw meat (and casings) prior to further production steps. Other research in our lab (Gaydos et al., 2016; Rivera-Reyes et al., 2017) indicated that organic acids are effective and important hurdles to add during the production of various comminuted products.

Although no statistical comparisons were made between pathogens on the same day or differing sampling days, it is interesting to note that $\mathrm{Lm}$ was the first pathogen to achieve a $5 \log _{10}$ reduction despite its welldocumented resistance to drying and high concentrations of salt (Hill et al., 2002; Gandhi and Chikindas, 2007; Swaminathan and Gerner-Smidt, 2007; Ferreira et al., 2014). Lm also persisted in higher levels $\left(\sim 1 \log _{10}\right)$ when compared with $E c$ and $\operatorname{Sal}\left(\sim 0.5 \log _{10}\right)$, which is consistent with Rainaldi et al. (1991), who showed that $\mathrm{Lm}$ could survive on dried bresaola for $7 \mathrm{~d}$. Attention should be drawn to the numerical increase in the concentration of Sal from day 23 to day 30. There was no statistical difference $(P=0.4049)$ between day 23 and day 30 for mean populations of $\mathrm{Sal}$, which is further support for the conclusion that this increase is not indicative of true "growth" of the pathogen.

The results of this validation study indicate that the parameters used to cure $\left(\geq 3.5 \%\right.$ salt, $150 \mathrm{ppm} \mathrm{NaNO}_{2}$, and $100 \mathrm{ppm} \mathrm{NaNO}_{3}$ ) and dry (surface $a_{W} \leq 0.85$ ) whole-muscle beef products are able to achieve a minimum 5-log reduction of $E c, S a l$, and $\mathrm{Lm}$. The combination of the antimicrobial intervention $(2.5 \%$ [vol/ vol] Beefxide spray), curing ingredients (salt, $\mathrm{NaNO}_{3}$, and $\left.\mathrm{NaNO}_{2}\right)$ and refrigerated curing parameters $\left(2^{\circ} \mathrm{C}-\right.$ $4^{\circ} \mathrm{C}$ for $\left.28 \mathrm{~d}\right)$ as well as the drying schedule $\left(12^{\circ} \mathrm{C}-\right.$ $14^{\circ} \mathrm{C} ; 65 \%-75 \%$ relative humidity for $35 \mathrm{~d}$ minimum) allow for a consistent decrease in both the pathogen populations and $a_{W}$. The levels of pathogens used in this challenge study indicate a worst-case scenario for pathogens present on beef products that would not likely be present in such high concentrations in a sanitary processing environment using reputable source materials. Although survival of each pathogen type was evident, the combination of hurdles, both intrinsic and extrinsic factors, does not allow for cell recovery and growth on this product.

\section{Conclusions}

Despite lack of scientific literature for the safety of artisanal and dry-cured meat products, consumer demand continues to increase for these types of products. Controlled curing with salt and $\mathrm{NaNO}_{3}$ and
$\mathrm{NaNO}_{2}$ is essential for product flavor, color, and safety. Drying, although primarily performed for quality reasons, is paramount to the safety of beef bresaola because a thermal lethality step is not typically utilized. Humidity control during drying will ensure consistent texture and mouthfeel that is expected by the consumer as well as provide critical and consistent reduction in $a_{W}$ for both external and internal product surfaces. Meat processors may utilize the results of this research for Hazard Analysis Critical Control Point supporting documentation and scientific validation for the production of raw, RTE bresaola, provided that production procedures follow the previously stated minimum safety parameters for curing and drying as well as incorporate the antimicrobial treatment on raw beef subprimals and casings.

\section{Acknowledgments}

This project was funded in part by Hatch project PEN04562, and the research protocols were reviewed and approved by the Penn State Office of Research Protection (IBC \#47758).

\section{Literature Cited}

Barkocy-Gallagher, G. A., K. K. Edwards, X. Nou, J. M. Bosilevac, T. M. Arthur, S. D. Shackelford, and M. Koohmaraie. 2005. Methods for recovering Escherichia coli O157:H7 from cattle fecal, hide, and carcass samples: Sensitivity and improvements. J. Food Protect. 68:2264 2268. https://doi.org/10. 4315/0362-028x-68.11.2264.

Beales, N. 2004. Adaptation of microorganisms to cold temperatures, weak acid preservatives, low $\mathrm{pH}$, and osmotic stress: A review. Compr. Rev. Food Sci. F. 3:1-20. https://doi.org/ 10.1111/j.1541-4337.2004.tb00057.x.

Brichta-Harhay, D. M., M. N. Guerini, T. M. Arthur, J. M. Bosilevac, N. Kalchayanand, S. D. Shackelford, T. L. Wheeler, and M. Koohmaraie. 2008. Salmonella and Escherichia coli O157:H7 contamination on hides and carcasses of cull cattle presented for slaughter in the United States: an evaluation of prevalence and bacterial loads by immunomagnetic separation and direct plating methods. Appl. Environ. Microb. 74:6289-6297. https://doi.org/10. 1128/AEM.00700-08.

Burnham, G. M., D. J. Hanson, C. M. Koshick, and S. C. Ingham. 2008. Death of Salmonella serovars, Escherichia coli O157: H7, Staphylococcus aureus and Listeria monocytogenes during the drying of meat: A case study using biltong and droëwers. J. Food Safety. 28:198-209. https://doi.org/10. 1111/j.1745-4565.2008.00114.x.

Castro, V. S., R. C. T. Carvalho, C. A. Conte-Junior, and E. E. S. Figuiredo. 2017. Shiga-toxin producing Escherichia coli: Pathogenicity, supershedding, diagnostic methods, occurrence, and foodborne outbreaks. Compr. Rev. Food 
Sci. F. 16:1269-1280. https://doi.org/10.1111/1541-4337. 12302.

Duffy, G., E. Cummins, P. Nally, S. O’Brien, and F. Butler. 2006. A review of quantitative microbial risk assessment in the management of Escherichia coli $0157: \mathrm{H} 7$ on beef. Meat Sci. 74:76-88. https://doi.org/10.1016/j.meatsci.2006. 04.011.

Elder, R. O., J. E. Keen, G. R. Siragusa, G. A. Barkocy-Gallagher, M. Koohmarai, and W. W. Laegreid. 2000. Correlation of enterohemorrhagic Escherichia coli $\mathrm{O} 157$ prevalence in feces, hides, and carcasses of beef cattle during processing. P. Natl. Acad. Sci. USA. 97:2999-3003. https://doi.org/10.1073/pnas. 97.7.2999.

Fàbrega, A., and J. Vila. 2013. Salmonella enterica serovar Typhimurium skills to succeed in the host: Virulence and regulation. Clin. Microbiol. Rev. 26:308-341. https://doi. org/10.1128.CMR.00066-12.

Ferreira, V., M. Wiedmann, P. Teixeira, and M. J. Stasiewicz. 2014. Listeria monocytogenes persistence in food-associated environments: Epidemiology, strain characteristics, and implications for public health. J. Food Protect. 77:150-170. https:// doi.org/10.4315/0362-028X.JFP-13-150.

Gandhi, M., and M. L. Chikindas. 2007. Listeria: A foodborne pathogen that knows how to survive. Int. J. Food Microbiol. 113:1-15. https://doi.org/10.1016/j.ijfoodmicro.2006.07. 008 .

Gaydos, N. J., C. N. Cutter, and J. A. Campbell. 2016. Fate of pathogenic bacteria associated with production of pickled sausage using a cold fill process. J. Food Protect. 79:1693-1699. https://doi.org/10.4315/0362-028X.JFP-16039.

Guerzoni, M. E., R. Lanciotti, and P. S. Cocconcelli. 2001. Alteration in cellular fatty acid composition as a response to salt, acid, oxidative and thermal stresses in Lactobacillus helveticus. Microbiology+. 147:2255-2264. https://doi.org/ 10.1099/00221287-147-8-2255.

Harvey, P., and S. Leach. 1998. Analysis of coccal cell formation by Campylobacter jejuni using continuous culture techniques, and the importance of oxidative stress. J. Appl. Microbiol. 85:398-404. https://doi.org/10.1046/j.1365-2672. 1998.00532.x.

Hill, C., P. D. Cotter, R. D. Sleator, and C. G. M. Gahan. 2002. Bacterial stress response in Listeria monocytogenes: Jumping the hurdles imposed by minimal processing. Int. Dairy J. 12:273-283. https://doi.org/10.1016/S0958-6946 (01)00125-X.

Hospital, X. F., E. Hierro, and M. Fernández. 2014. Effect of reducing nitrate and nitrite added to dry fermented sausages on the survival of Salmonella Typhimurium. Food Res. Int. 62:410-415. https://doi.org/10.1016/j.foodres.2014.03. 055.

Leistner, L. 2000. Basic aspects of food preservation by hurdle technology. Int. J. Food Microbiol. 55:181-186. https://doi. org/10.1016/s0168-1605(00)00161-6.

Leistner, L., and L. G. M. Gorris. 1995. Food preservation by hurdle technology. Trends Food Sci. Tech. 6:41-46. https://doi.org/ 10.1016/S0924-2244(00)88941-4.
Majou, D., and S. Christieans. 2018. Mechanisms of the bactericidal effects of nitrate and nitrite in cured meats. Meat Sci. 145:273-284. https://doi.org/10.1016/j.meatsci.2018.06.013.

Montville, T. J., K. R. Matthews., and K. E. Kniel. 2012. Food microbiology: An introduction. 3rd ed. American Society for Microbiology Press, Washington, DC. p. 34-36, $170-220$

Murga, M. L. F., G. M. Cabrera, G. F. de Valdez, A. Disalvo, and A. M. Seldes. 2000. Influence of growth temperature on cryotolerance and lipid composition of Lactobacillus acidophilus. J. Appl. Microbiol. 88:342-348. https://doi.org/10.1046/j. 1365-2672.2000.00967.x.

Rainaldi, L., M. A. Luciani, and F. Picconi. 1991. Behavior of Listeria spp. in meat products. Ital. J. Food Sci. 4: 291-296.

Rivera-Reyes, M., J. A. Campbell, and C. N. Cutter. 2017. Pathogen reductions associated with traditional processing of landjäger. Food Control. 73:768-774. https://doi.org/10. 1016/j.foodcont.2016.09.047.

Rowan, N. J. 1999. Evidence that inimical food-preservation barriers alter microbial resistance, cell morphology and virulence. Trends Food Sci. Tech. 10:261-270. https://doi.org/10.1016/ S0924-2244(99)00060-6.

Ruhlman, M., and B. Polcyn. 2012. Salumi: The craft of Italian dry curing. W. W. Norton and Company, New York. p. 9-13, $180-181$

Scott, W. J. 1957. Water relations of food spoilage microorganisms. Adv. Food Res. 7:83-127. https://doi.org/10.1016/S00652628(08)60247-5.

Scott, V. N. 2005. How does industry validate elements of HACCP plans? Food Control. 16:497-503. https://doi.org/10.1016/j. foodcont.2003.11.013.

Sperber, W. H. 1983. Influence of water activity on foodborne bacteria- A review. J. Food Protect. 46:142-150. https://doi.org/ 10.4315/0362-028X-46.2.142.

Swaminathan, B., and P. Gerner-Smidt. 2007. The epidemiology of human listeriosis. Microbes Infect. 9:1236-1243. https://doi. org/10.1016/j.micinf.2007.05.011.

Federal Register. 1996. Pathogen Reduction; Hazard Analysis and Critical Control Point (HACCP) Systems [US Bill]. Vol. 61, Number 144. National Archives and Records Administration. https://www.govinfo.gov/content/pkg/FR-1996-07-25/pdf/ 96-17837.pdf. (Accessed 27 March 2020.)

USDA FSIS. 2014a. Compliance guidelines for Shiga toxin Escherichia coli (STEC) organisms sampled and tested labeling claims for boneless beef manufacturing trimmings ("beef trim"). US Department of Agriculture Food Safety and Inspection Service. https://www.fsis.usda.gov/sites/default/ files/import/Compliance-Guide-Ecoli-Tested-Claims.pdf. (Accessed 25 March 2020.)

USDA FSIS. 2014b. FSIS compliance guideline: Controlling Listeria monocytogenes in post-lethality exposed ready-toeat meat and poultry products. US Department of Agriculture Food Safety and Inspection Service. https://www. fsis.usda.gov/wps/wcm/connect/d3373299-50e6-47d6-a577e74a1 e549fde/Controlling-Lm-RTE-Guideline.pdf?MOD= AJPERES. (Accessed 1 May 2019.) 
USDA FSIS. 2017. FSIS Salmonella compliance guidelines for small and very small meat and poultry establishments that produce ready-to-eat (RTE) products and revised Appendix A. US Department of Agriculture Food Safety and Inspection Service. June 2017. https://www.fsis.usda.gov/wps/wcm/ connect/bf3f01a1-a0b7-4902-a2df-a87c73d1b633/SalmonellaCompliance-Guideline-SVSP-RTE-Appendix-A.pdf?MOD= AJPERES. (Accessed 1 May 2019.)
Zeuthen, P. 2007. A historical perspective of meat fermentation. In: F. Toldrá, editor, Handbook of fermented meat and poultry. Blackwell Publishing, Ames, IA. p. 1-8.

Zhou, G. H., X. L. Xu, and Y. Liu. 2010. Preservation technologies for fresh meat- A review. Meat Sci. 86:119-128. https://doi. org/10.1016/j.meatsci.2010.04.033. 